\title{
Touristification of cultural heritage, identities tested by marketing of handcrafts to tourists in Turkey: The case of Görece
}

\author{
Zafer Öter ${ }^{1 *}$
}

Received: 08/09/2009

\footnotetext{
1 Mugla University, School of Tourism and Hospitality Management, 48170, Kotekli - Mugla, Turkey; Tel: +90-252-2111854; email: oter@hotmail.com

* Corresponding author
}

Supervisor: Christian Bataillou, Ph.D.

Institution awarding the Ph. D. Degree: University of Perpignan Via Domitia, Transborder Franco Catalan Institute, Center of Catalan Research and Education, Perpignan, France

Date of defence: $10^{\text {th }}$ July 2009

(c) 2010 International University College. All rights reserved

Citation: Öter, Z. (2010) Touristification of cultural heritage, identities tested by marketing of handcrafts to tourists in Turkey: The case of Görece. Doctoral dissertation summary. European Journal of Tourism Research 3(1), pp. 77-79

\section{Goal and objectives of the dissertation Goal}

The goal of this doctoral dissertation is to question qualitatively the current status of intangible cultural heritage valorisation efforts in Turkey and analyze marketing process of traditional local handcrafts via tourism industry with an emphasis on identity and commercialisation problems.

\section{Objectives}

- Analyze and assess cultural heritage supply for Turkish tourism

- Differentiate tangible and intangible cultural heritage as tourism resources

- Analyze concepts of handcraft, art, and design, underline the place of handcraft in modern ages

- Explore the use of culture for economic purposes and use of tourism as the scene of cultural industries

- Explain the stages of cultural heritage valorisation process and underline the importance of cultural heritage marketing for sustainability

- Probe problems of tourist shopping regarding handcrafts and souvenirs

- Analyze in detail the handcraft production and marketing in small rural communities in Turkey

- Explain marketing process of handcraft as intangible cultural heritage through the case of a village close to Izmir city being the historical and current centre of blowlamp glass production (and also traditional evil eyes) in Turkey

- Develop recommendations for craftsmen and tourism practitioners in order to develop a balanced 
Touristification of cultural heritage, identities tested by marketing of handcrafts to tourists in Turkey: The case of Görece. Doctoral dissertation summary

relationship between valorisation, protection and marketing of local cultural heritage

\section{Methodology}

Qualitative research approach was preferred to analyze the problem. As the underlying research paradigm was qualitative, data collection procedures aimed to produce descriptive, interpretive data. Choice of qualitative approach was necessary keeping in mind the complex reality and unorganized structure of handcraft production in Turkey. Therefore; the methodology of the study was decided to obtain introductory and exploratory data (Why and How questions) to understand circumstances and limits of the field rather than achieving causal results. The research design used was the cross-case case-study. This design allowed combining three sub cases (an Istanbul based international firm exporting Turkish handcrafts; an Izmir based local firm selling handcraft to tourists; and people representing local craft in a village) in a global case: Görece village historical centre of blowlamp glass craft in Turkey. Before data collection the instrument (semi-structured indepth interview questionnaire) was developed. The primary data were obtained with semi-structured in-depth interviews from individual key informants and documentary studies on the field (filming, photography, voice recording) and unstructured observation as data collection techniques. The data collection techniques were multiplied to obtain higher level of validity in its analysis. In addition; secondary data were obtained from literature and media archives. The study is limited geographically to a rural craft village that received immigrants since 1980s, and its content is limited to the analysis of blowlamp glass craft (handmade glass objects such as evil eye, blue beads... from melted glass in traditional furnaces) representing handcraft domain and Turkish cultural heritage. Sampling technique adopted was snowball sampling because uncertainty level was high to find relevant interviewees. The analysis of the qualitative data aimed to produce meaningful patterns and themes from analytical interpretations. Analysis of the data required data reduction at first step, because the amount of data accumulated was very high. Selected parts of the data were simplified, abstracted and transformed with inductive and deductive analysis. Visual data display was used. A conceptual analytical model based on the questionnaire was followed to analyze data with several direct quotations from the interviewees. Final part of data analysis concentrated on conclusion drawing and verification where introductory questions reflecting research objectives were revisited. Lessons learned about cultural heritage marketing of Görece village were discussed in relation with theoretical bases and socio-cultural impact. Findings are developed to produce theoretical insights, practical recommendations for public and private sectors.

\section{Results}

Rural communities and villages having artisanal, handcraft traditions in Turkey confront serious problems in marketing their handmade products to tourism industry as a result of globalized economic conditions and some local factors. Rural depopulation and immigration create identity conflicts and cultural heritage becomes an identity builder for groups. Traditional know-how and certain jobs are under threat of being forgotten, public awareness on cultural heritage valorisation in Turkey increases, but the need to develop new tools for intangible cultural heritage including marketing aspects continue.

\section{Theoretical conclusions}

Mass tourism, automated production systems, extensive technology use, and changing values of modernity put in danger some traditional jobs. Rural zones are depopulated by young people because of economic problems. Revitalizing rural zones and saving local cultural heritage through tourism is a recent but popular trend. Marketing of cultural products to tourists in forms of art, souvenir or functional objects need careful planning between local producers, municipality, commercial structure, tourism industry, and cultural policy developers. Different types of cultural heritage may require different marketing strategies to tourism. Economic 
conditions change social and demographic structures in rural villages and immigrated population keep their cultural heritage as identity maker as long as they can receive economic benefits from this heritage.

\section{Practical application of the dissertation}

From the local perspective of craftsmen crucial concerns are: eliminating the middlemen, limiting low quality manufactured imitations; pulling tourist to the production area, and communicating the quality of local products by labels. Local craftsmen are individually weak producers but they can work in form of cooperatives and control the production and marketing costs.

\section{Content of the dissertation}

Abstract of chapter one

Cultural Heritage, Traditional Handcrafts and Tourism relations are discussed. Small enterprises and craftsmen are differentiated from artistic handcraft producers. Culture as a term is defined and its several facets (subculture, acculturation etc.) are discussed. Culture-economy relation; cultural industries and cultural products are presented. The role of souvenir and tourist art and the problems with tourist shopping are given. Cultural tourism is explained as a specialized tourism form.

\begin{abstract}
of chapter two
Tourism marketing, cultural heritage and handcrafts are analyzed in Turkish context. Supply and demand, natural and cultural heritage use in Turkish tourism, UNESCO World Heritage List in Turkey, Turkish traditional handcrafts (arts and crafts) are discussed. Marketing of Turkish traditional handcrafts is questioned from public and private sector prisms. The organizational structure of Turkish craftsmen and their education are outlined from historical $\mathrm{AHI}$ Guilds to modern Professional Commercial Chambers.
\end{abstract}
Abstract of chapter three
Marketing of Turkish traditional handcraft via tourism industry and issues related are questioned by a case study encompassing a traditional village. The multi-level case study combined three sub-categories analyzing opinions of local craftsmen (evil eye producers with blowlamp glass), local traders selling products of the village, and an international trade firm exporting Turkish handcrafts. Semi-structured in-dept interviews sought to learn two axes related with the topic; cultural heritage valorisation procedures observed, and marketing mix (product, price, place, promotion) considerations about "evil eye" and other glasswork sales to tourists. 